\title{
Establishment and Escalation of an Amino Acid Stacked Repressible Release Embedded System Using Quality by Design
}

\author{
Tasarım Üzerinde Kaliteyi Kullanarak Amino Asit Yığılmış Bastırılabilir \\ Salınan Gömülü Sistemin Kurulması ve Arttırılması
}

\author{
(D) Vijay SHARMA ${ }^{*}$, (D) Lalit SINGH ${ }^{1}$, (D) Navneet VERMA 2 \\ 1Shri Ram Murti Smarak College of Engineering, Technology and Research, Bareilly, India \\ 2IFTM University, Faculty of Pharmacy, Moradabad, India
}

\begin{abstract}
Objectives: The traditional approach of developing a new delivery system is an exhaustive task and requires a number of resources like manpower, money, material, and time. To overcome this problem Quality by Design (QbD) can be utilized to obtain pharmaceutical products of desired (best) quality with minimum use of the above resources as well as determination of the impact of one factor over the desired associated process. The present research is focused on establishing a design for formulating optimized gelatin microspheres using QbD.

Materials and Methods: Repressible released embedded microspheres of L-arginine were prepared by performing cross linking of gelatin using glutaraldehyde. Characterization of the formulated embedded microspheres was done based on infrared spectroscopy, scanning electron microscopy, percentage yield, microsphere size, drug entrapment efficiency, and drug release. The impact of concentrations of gelatin and ethyl cellulose was determined over dependent response like percentage yield, microsphere size, and drug entrapment efficiency.

Results: A response surface curve was obtained using a $3^{2}$ central composite design and the optimized batch was obtained with percentage yield, microsphere size, and drug entrapment efficiency of $89.98,333.32 \mathrm{~mm}$, and $82.61 \%$, respectively. Validation of the optimized batch was done by formulating four different batches with optimized values of independent response and a comparison of the observed responses with the predicted ones was set up and all these batches were found close to the predicted values and show the validity of the optimized data.

Conclusion: The QbD approach is quite efficient to get optimized drug delivery systems of L-arginine without exhaustive study.

Key words: L-arginine, gelatin, central composite design, microspheres, characterization of microspheres
\end{abstract}

öz

Amaç: Yeni bir doğum sisteminin geliştirilmesine yönelik geleneksel yaklaşım, kapsamlı bir görevdir ve insan, para, malzeme ve zaman gibi birtakım kaynakları gerektirir. Bu sorunun üstesinden gelmek için Tasarım Üzerinde Kalite (QbD), istenen (en iyi) kalitenin farmasötik ürününün, yukarıda belirtilen kaynakların asgari kullanımı ile istenilen ilgili süreç üzerinde bir faktörün etkisinin belirlenmesi için kullanılmasını sağlar. Bu araştırma, QbD'yi kullanarak optimize edilmiş jelatin mikroküreleri formüle etmek için bir tasarım oluşturulmasına odaklanmıştır.

Gereç ve Yöntemler: Yeniden basılabilir serbestleștirilmiș L-argininin mikro-küreleri, glutaraldehit kullanılarak jelatinin çapraz bağlanmasıyla hazırlandı. Formüle edilmiş mikrosferlerin karakterize edilmesi kızı ötesi spektroskopi, taramalı elektron mikroskobu, yüzde verimi, mikroskop boyutu, ilaç tutma verimi ve ilaç salınımı ile yapıldı. Jelatin ve etil selüloz konsantrasyonunun etkisi, yüzde verimi, mikro küre boyutu ve ilaç tutma verimi gibi bağımlı tepki üzerinde belirlenmiștir.

Bulgular: Yanıt merkezi eğrisi 32 merkezi kompozit dizayn kullanılarak elde edildi ve sırasıyla yüzde verim, mikro küre boyutu ve ilaç tutma verimi 89.98, $333.32 \mathrm{~mm}$ ve \%82.61 olarak optimize edilmiş toplu elde edildi. Optimize edilmiş partinin geçerliliği, bağımsız yanıtın optimize edilmiş değerleri ile dört farklı parti formüle edildi ve gözlemlenen yanıtların öngörülen değerlerle karşılaştırılması ve tüm bu partilerin öngörülen değerlerin yakınında bulunduğu ve düzgünleștirilmiş verilerin geçerliliğini gösterdiği bulundu.

Sonuç: QbD yaklaşımı, aşırı etkili çalışma yapmadan L-argininin optimize edilmiş ilaç verme sistemlerini elde etmek için oldukça etkilidir.

Anahtar kelimeler: L-arginin, jelatin, merkezi kompozit tasarımı, mikrosferler, mikrosferlerin karakterizasyonu

*Correspondence: E-mail: vijaysrampur@gmail.com, Phone: +91945872561 ORCID-ID: orcid.org/0000-0003-1898-0476

Received: 02.08.2017, Accepted: 07.12.2017

๑Turk J Pharm Sci, Published by Galenos Publishing House. 


\section{INTRODUCTION}

Quality by Design (QbD) is a helpful tool for systemic development of drug formulations based on sound scientific principles; it refers to the successful achievement of predictable quality with desired predetermined specification and without doing exhaustive conventional study. The QbD paradigm of drug regulation necessitates very good understanding of the product to overcome future product failures. ${ }^{2}$ Design of experiment and response surface method help in finding the individual as well as combined effects of variables on a product. ${ }^{3,4}$

Oral controlled release formulations are developed to lessen the problems associated with oral conventional dosage forms; for example, they can reduce side effects and improve therapeutic efficacy by delayed/prolonged drug release so that the frequency of drug administration can be reduced, thus assuring better patient compliance. ${ }^{5,6}$ Various techniques have been developed for controlled release formulations; they utilize the cross-linking ability of polyelectrolyte in the presence of counter ions to form a multiparticulate system. These delivery systems are spherical cross linked hydrophilic polymeric systems, which upon gelation and swelling in simulated biological fluids release the drug in a controlled manner. These developed microspheres can be loaded with high amounts of drug compared to the conventional delivery system. ${ }^{7,8}$

Arginine, an ergogenic (i.e., performance enhancing) supplement, most notably in the nitric oxide (NO) class of supplements, is a semi-essential amino acid involved in multiple areas of human physiology and metabolism. NO produced from it improves outcomes in various diseases. ${ }^{9}$ L-arginine is readily available over the counter and is popular as a nutritional supplement to increase muscle mass. Recently, L-arginine has been tested as a potential therapeutic in numerous acute and chronic disease states, including sickle cell chest crisis, pulmonary artery hypertension, coronary heart disease, pre-eclampsia, and myocardial infarction, because of its bronchodilator and vasodilator actions..$^{10,11}$

\section{MATERIALS AND METHODS}

\section{Materials}

L-arginine was obtained from CDH Laboratory Chemicals and sodium alginate (low viscosity grade, $250 \mathrm{cp}$ of $2 \%$ solution at $25^{\circ} \mathrm{C}$ ) from Loba Chemie Pvt. Ltd (Mumbai). Gelatin, ethyl cellulose (EC), and Span 80 were purchased from Thermo Fisher Scientific India Pvt. Ltd. (Mumbai). Glutaraldehyde and light liquid paraffin were procured from Loba Chemie (Mumbai). All other chemicals used in the study were of analytical grade. high performance liquid chromatography (HPLC) grade water, methanol, and potassium dihydrogen orthophosphate were purchased from Qualigens Fine Chemicals (Gujrat).

\section{Methods}

\section{Preparation of microspheres}

Controlled release microspheres of $\mathrm{L}$-arginine were prepared by cross linking of gelatin using glutaraldehyde. The required amount of gelatin was placed in a beaker; to this $8 \mathrm{~mL}$ of distilled water was added and this mixture was heated at $40^{\circ} \mathrm{C}$ for $3-4$ min to get a uniform polymer mixture. Different concentrations of EC were added as shown in Table 1. Then the specified amount of drug was dispersed thoroughly to the polymer solution. A mixture of light liquid paraffin $(200 \mathrm{~mL})$ and Span $80(0.1 \mathrm{~mL})$ was prepared. The mixture was maintained at $4^{\circ} \mathrm{C}$ with an ice bath and stirred at $200 \mathrm{rpm}$ and to this mixture previously prepared polymeric drug solution was added through a syringe with a 22-gauge needle. After some time glutaraldehyde $(2 \mathrm{~mL})$ was added dropwise to it with continuous stirring for $2 \mathrm{~h}$. The microspheres were filtered, washed with iso-propyl-alcohol to remove the liquid paraffin, and dried at room temperature. Then the dried microspheres were collected, weighed, and stored. ${ }^{12,13}$

\section{$3^{2}$ central composite design}

A $3^{2}$ central composite design (CCD) was adopted for the optimization study. The two independent variables investigated were functional excipients such as concentrations of gelatin $(\mathrm{X})$ and $\mathrm{EC}(\mathrm{Y})$. The impact responses of these independent variables were investigated on the dependent responses such as percentage yield, microsphere size (MS), and drug entrapment efficiency (DEE). The experimental points used according to the design are shown in Table 1.

Polynomial equations were generated and used to express the function of independent variables. A common polynomial equation to observe the effect of an independent variable can be expressed as,

$Y_{1}=b_{0}+b_{1} X_{1}+b_{2} X_{2}+b_{3} X_{1} X_{2}+b_{4} X_{12}+b_{5} X_{22}+b_{6} X_{1} X_{22}+b_{7} X_{12} X_{2^{\prime}}$ eqn. (1)

where $Y_{1}$ is the dependent variable and $b_{0}$ is the arithmetic mean response of 13 runs.

Table 1. Formulation design and their coded value

\begin{tabular}{lllll} 
Batch & Coded value & \multicolumn{3}{l}{ Actual value } \\
\cline { 2 - 5 } code & $\begin{array}{l}\text { Factor A } \\
\text { gelatin }(\mathrm{mg})(\mathrm{X})\end{array}$ & $\begin{array}{l}\text { Factor B } \\
\text { EC }(\mathrm{mg})(\mathrm{X})\end{array}$ & $\begin{array}{l}\text { Factor A } \\
\text { gelatin }(\mathrm{mg})(\mathrm{X})\end{array}$ & $\begin{array}{l}\text { Factor B } \\
\text { EC }(\mathrm{mg})(\mathrm{X})\end{array}$ \\
\hline B1 & +1 & -1 & 1000 & 50 \\
\hline B2 & +1 & 0 & 1000 & 100 \\
\hline B3 & +1 & +1 & 1000 & 150 \\
\hline B4 & 0 & -1 & 900 & 50 \\
\hline B5 & 0 & 0 & 900 & 100 \\
\hline B6 & 0 & +1 & 900 & 150 \\
\hline B7 & -1 & -1 & 800 & 50 \\
\hline B8 & -1 & 0 & 800 & 100 \\
\hline B9 & -1 & +1 & 800 & 150 \\
\hline B10 & 0 & 0 & 900 & 100 \\
\hline B11 & 0 & 0 & 900 & 100 \\
\hline B12 & 0 & 0 & 900 & 100 \\
\hline B13 & 0 & 0 & 900 & 100 \\
\hline EC: Ey & 0 & & & \\
\hline
\end{tabular}

EC: Ethyl cellulose 
The main independent variables, that is, effects $X_{1}$ and $X_{2}$, represent the average result of changing one factor at a time from its lower values to its higher values. The $3^{2}$ CCD is the most efficient tool for estimating the influence of individual variables (main effects) and their interactions using minimum experimentation. In the present research, the $3^{2}$ CCD was considered to be best as the values of the response surfaces were not known from the previous findings. Thus, this design was selected for optimization of the formulated microspheres.

\section{Evaluation of prepared microspheres}

\section{Characterization of microspheres}

Fourier-transform infrared (FTIR) spectra was obtained using a Jasco FTIR 6100 type A spectrometer (Japan), the sample was prepared in $\mathrm{KBr}$ disks, and the spectra were recorded over the wavenumber $4000-400 \mathrm{~cm}^{-1}$. All three spectra were completely analyzed.14

\section{Percentage yield}

Microspheres dried at room temperature were weighed and the percentage yield of microspheres was calculated using the formula: $:^{14}$

$\%$ yield $=\frac{\text { Amount of sphere prepared experimentally }}{\text { Theoretical amount of microspheres (mg) }} \times 100$ eqn. (2)

\section{Morphological analysis}

A scanning electron microscope (Zeiss, Supra 40, India) was used to characterize the surface topography of the microspheres. The microspheres were fixed on a brass support using thin adhesive tape and the samples were coated with thin layer gold under vacuum to render them electrically conductive (approximately $3000 \AA$ ). The surface picture was taken at $15 \mathrm{kV}$ and $20 \mathrm{kV}$ for the drug-loaded microspheres.

\section{Particle size determination of microspheres}

Particle size was analyzed by sieving. Microspheres were separated out in different size fractions by passing them through a set of sieves over $5 \mathrm{~min}$. This set of sieves included standard sieves having nominal mesh apertures of $1.0 \mathrm{~mm}$, $0.71 \mathrm{~mm}$, and $0.5 \mathrm{~mm}$ (sieve no. 16, 22, and 30, respectively). The particle size distributions of the beads were determined and mean particle sizes of beads were calculated using the following formula:

$$
\text { Mean particle size }=\frac{\left.\sum \text { (Mean particle size of the fraction } \mathrm{x} \text { weight }\right)}{\sum \text { Weight fraction }} \text { eqn. (3) }
$$

\section{Swelling index}

The gelatin microspheres were kept in double distilled water for swelling for $1 \mathrm{~h}$ to achieve maximum swelling. Volumetric measurements were made by determining the increase in volume in the swelling medium at specific time intervals. The swelling index was calculated as follows: ${ }^{15}$

Swelling index $=\frac{\text { Volume of swollen particles }}{\text { Volume of dry particles }}$ eqn. (4)

\section{Drug entrapment efficiency}

Accurately weighed drug-loaded microspheres equivalent to $100 \mathrm{mg}$ of $\mathrm{L}$-arginine were added to $0.1 \mathrm{~N} \mathrm{HCl}$ and shaken on a mechanical shaker for $24 \mathrm{~h}$. Then the solution was filtered and the drug content was estimated spectrophotometrically using HPLC (Younglin, ACME-9000, China). The drug entrapment efficiency was determined using the following formula: ${ }^{16}$

Drug entrapment efficiency $=\frac{\text { Actual drug content }}{\text { Theoretical drug content }} \times 100$ eqn. (5)

In vitro drug release

In vitro release studies were carried out on L-arginine loaded microspheres using a USP XXIV dissolution test apparatus-I (Electrolab, TDT-06T, Maharashtra, India). Weighed quantities of microcarriers equivalent to $100 \mathrm{mg}$ of L-arginine were introduced into a dissolution basket and the basket was placed in $900 \mathrm{~mL}$ of phosphate buffer solution ( $\mathrm{pH} 7.4$ for $8 \mathrm{~h}$ ) at $37 \pm 0.5^{\circ} \mathrm{C}$ (Ph. US $24^{\text {th }} \mathrm{edn}$ ) and $50 \mathrm{rpm} .{ }^{17}$ Aliquots of $5 \mathrm{~mL}$ of solution were withdrawn at specific time intervals and replaced with fresh dissolution medium. The withdrawn samples were analyzed for drug content by HPLC (Younglin, ACME-9000, China) using a ultraviolet detector. The samples were studied at $210 \mathrm{~nm}$ to obtain the retention time of 2.2-2.4 min and AUC. ${ }^{18}$ The results of the in vitro release data were fitted into various release equations and kinetic models. ${ }^{19-21}$

\section{Optimization and data validation}

Concentrations of gelatin were selected as 1000, 900, and 800 $\mathrm{mg}$, whereas for EC they were 50, 100, and $150 \mathrm{mg}$. Thirteen formulations were developed by selecting nine possible combinations among which the center point was repeated four times and the mean value was taken for further study. The dependent responses were analyzed using Design Expert ${ }^{\circledR}$ 8.0.7.1 (trial version). The models were tested for significance and the optimized batch was selected with desired values of dependent responses. Four formulations (VCB1 to VCB4) along with the optimized batch were developed and validated by response surface methodology. The observed and predicted responses were critically compared. Linear correlation plots were constructed for the chosen check-point formulations. The residual graphs between predicted and observed responses were also constructed separately and the percent prediction error (\% bias) was calculated with respect to the observed responses. The optimized batch was validated taking a total of four formulations selected as check-points.

\section{RESULTS}

The FTIR profile of the formulated microspheres was obtained to identify the drug-polymer interaction. Hence the formulated microspheres were subjected to IR analysis to evaluate the possible interaction between drug and polymer. The infrared curve of pure drug and formulated microspheres shows similar peaks (Table 2, Figure 1), which confirms that there is no interaction between drug and polymer. 
Table 2. IR interpretation of optimized L-arginine microspheres

\begin{tabular}{|c|c|}
\hline IR frequencies $\left(\mathrm{cm}^{-1}\right)$ & Assignments \\
\hline 3158.57 & $\mathrm{NHStr}$ \\
\hline 2935.78 & $\mathrm{CH}_{3} \mathrm{Str}$ \\
\hline 1681.04 & $\mathrm{NH}_{2}$ Bend \\
\hline 1576.87 & CO Str \\
\hline 1517.08 & $\mathrm{OH}$ Bend \\
\hline 1458.25 & $\mathrm{CH}_{3}$ Asy Bend \\
\hline 1407.13 & $\mathrm{CH}_{3}$ Sym Bend \\
\hline 1356.02 & $\mathrm{CH}_{3}$ Sym Bend \\
\hline 1320.33 & $\mathrm{OH}$ Bend \\
\hline 1176.56 & Sym Str CCC Bond \\
\hline 899.46 & $\mathrm{NH}_{2}$ Bend \\
\hline 521.77 & CO Bend \\
\hline 447.50 & $\mathrm{NH}_{2}$ Rock \\
\hline
\end{tabular}

IR: Infrared
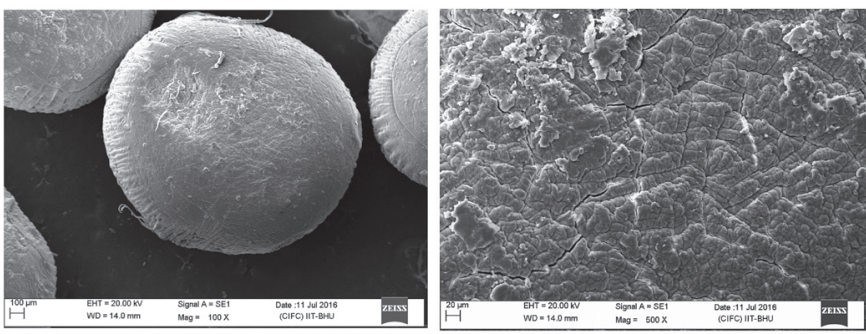

Figure 1. Scanning electron micrograph of microspheres, a) single bead, b) enlarged surface view

\section{Surface topography}

Scanning electron microscopy was used to investigate the surface topography of prepared microspheres and the result is shown in Figure 2.

The percentage yield and mean particle size of the formulation are given in Table 3.

\section{Drug entrapment efficiency}

DEE is an important variable used to assess the drug loading capacity of microspheres and their drug release profile. DEE

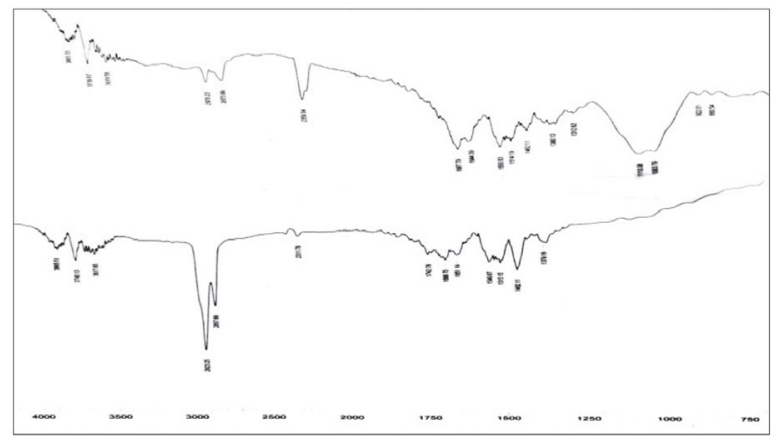

Figure 2. FTIR spectra of a) L-arginine and, b) formulated microspheres FTIR: Fourier-transform infrared depends upon various parameters such as the process used for preparation, physicochemical properties of the drug, and various formulation variables (Table 3 ).

\begin{tabular}{|c|c|c|c|}
\hline Batch code & Yield\% & Mean particle size $(M S)(\mu m)$ & DEE (\%) \\
\hline B1 & 83.55 & 326.81 & $75.32 \pm 2.261$ \\
\hline B2 & 86.36 & 329.38 & $78.0 \pm 2.458$ \\
\hline B3 & 89.98 & 333.32 & $80.15 \pm 0.794$ \\
\hline B4 & 77.98 & 315.98 & $73.59 \pm 1.744$ \\
\hline B5 & 80.07 & 318.59 & $75.43 \pm 1.877$ \\
\hline B6 & 83.44 & 321.53 & $78.76 \pm 1.572$ \\
\hline B7 & 74.65 & 302.34 & $75.09 \pm 0.872$ \\
\hline B8 & 75.45 & 307.08 & $78.15 \pm 0.519$ \\
\hline B9 & 77.21 & 311.65 & $82.61 \pm 0.700$ \\
\hline B10 & 81.07 & 317.73 & $75.87 \pm 0.519$ \\
\hline B11 & 80.32 & 317.89 & $76.67 \pm 0.519$ \\
\hline B12 & 80.54 & 316.52 & $77.05 \pm 0.519$ \\
\hline B13 & 79.96 & 315.65 & $75.14 \pm 0.519$ \\
\hline
\end{tabular}

MS: Microsphere size, DEE: Drug entrapment efficiency

\section{In vitro release behavior of drug}

The in vitro drug release behavior of the formulated glutaraldehyde cross-linked gelatin microspheres is shown in Figure 3. All batches were studied for their drug release profile for up to 8 hits and it was observed that in all formulated systems the rate of release varied due to the use of different concentrations of dependent variables. It is clear that as the amount of EC increases from 50 to $150 \mathrm{mg}$ the rate of drug release decreases, which indicates the hydrophobic nature of EC in the formulation; hence increasing amounts of EC lead to retardation in drug release. The cross linking property of glutaraldehyde leads to the formation of a rigid hydro gel to restrict leaching, thereby decreasing drug dissolution (Table 4, Figure 3).

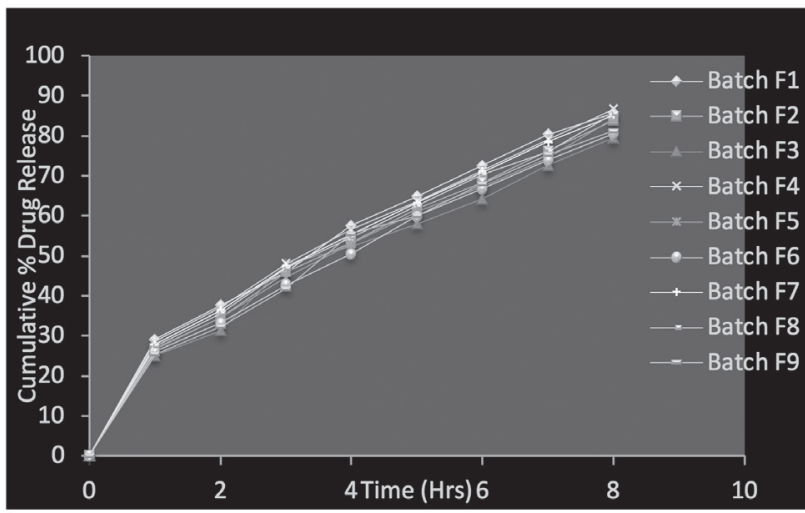

Figure 3. In vitro evaluation of $\mathrm{L}$-arginine loaded gelatin microspheres 


\section{Table 4. Drug release kinetics study}

\begin{tabular}{lllllll}
$\begin{array}{l}\text { Batch } \\
\text { code }\end{array}$ & $\mathrm{DR}_{8}$ & $\begin{array}{l}\text { Korsmeyer } \\
\mathrm{R}^{2}\end{array}$ & $\begin{array}{l}\text { Higuchi } \\
\mathrm{R}^{2}\end{array}$ & $\begin{array}{l}\text { First- } \\
\text { order } \mathrm{R}^{2}\end{array}$ & $\begin{array}{l}\text { Zero- } \\
\text { order } \mathrm{R}^{2}\end{array}$ & $\mathrm{n}$ \\
\hline $\mathrm{B} 1$ & 85.754 & 0.9781 & 0.9953 & 0.9881 & 0.9122 & 0.4590 \\
\hline B2 & 83.963 & 0.9773 & 0.9935 & 0.9835 & 0.9325 & 0.4955 \\
\hline B3 & 79.508 & 0.9796 & 0.9917 & 0.9824 & 0.9474 & 0.4875 \\
\hline B4 & 86.693 & 0.9774 & 0.9955 & 0.9837 & 0.9263 & 0.4848 \\
\hline B5 & 84.323 & 0.9757 & 0.9920 & 0.983 & 0.9346 & 0.4826 \\
\hline B6 & 80.454 & 0.9778 & 0.9923 & 0.9869 & 0.9396 & 0.4905 \\
\hline B7 & 85.255 & 0.9633 & 0.9901 & 0.9830 & 0.9193 & 0.4861 \\
\hline B8 & 85.617 & 0.978 & 0.9892 & 0.9833 & 0.9268 & 0.4566 \\
\hline B9 & 81.194 & 0.972 & 0.9918 & 0.978 & 0.9351 & 0.4664 \\
\hline
\end{tabular}

\section{Data analysis and optimization}

The drug release mechanism was investigated by fitting to models representing zero-order, first-order, Higuchi's square root of time, and Korsmeyer-Peppas models. Results of ANOVA for the response surface quadratic model for various dependent parameters were as follows:

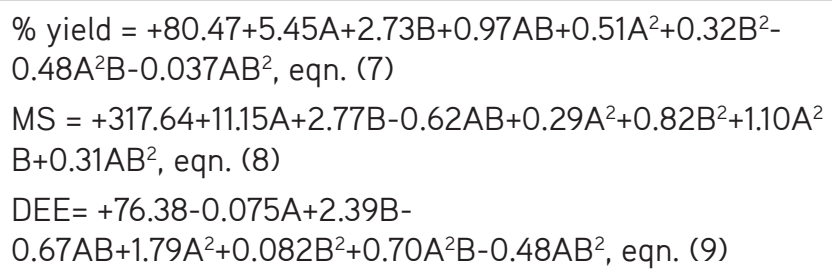

where $\mathrm{A}$ indicates the concentration of gelatin and $\mathrm{B}$ represents the concentration of EC.

Figure 4 shows response surface and contour plots for \% yield, MS and DEE.

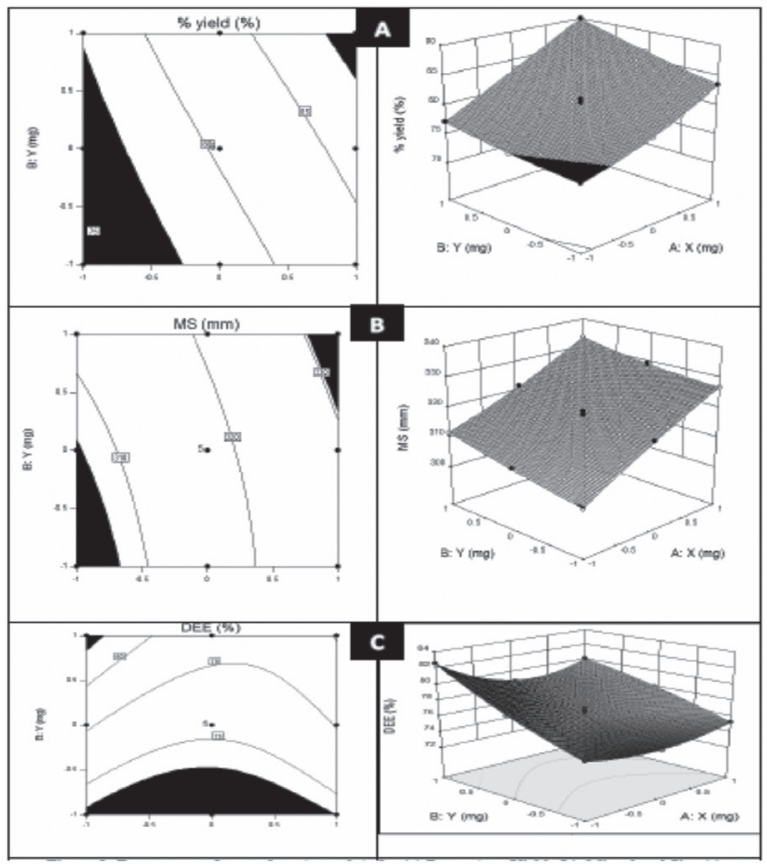

Figure 4. Response surface methodology and contour plots for a) percentage yield, b) microsphere size, c) drug entrapment efficiency
Validation of the statistical model

Validation of the optimized batch was done by formulating four different batches using an overlay plot (Figure 5) by utilizing the optimum value as found by statistical analysis, i.e., by considering the optimum value found (Table 5) and a comparative study was done between predicted values and observed values to determine the prediction error (Figure 6).

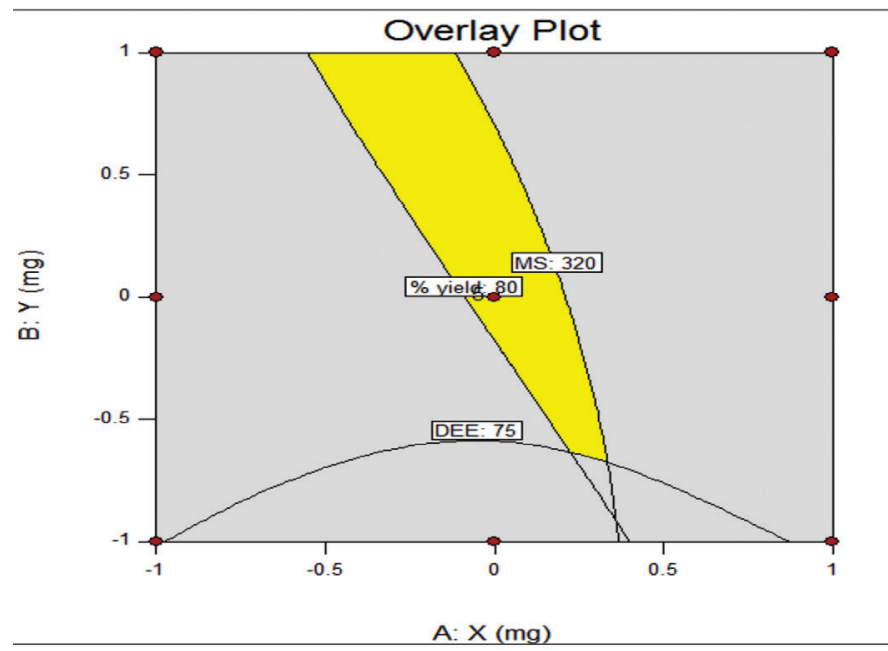

Figure 5. Overlay plot showing area for optimized product

\begin{tabular}{|c|c|c|c|c|}
\hline $\begin{array}{l}\text { Validation check } \\
\text { batch }\end{array}$ & Response & $\begin{array}{l}\text { Predicted } \\
\text { value }\end{array}$ & $\begin{array}{l}\text { Experimental } \\
\text { value }\end{array}$ & $\begin{array}{l}\text { Percent } \\
\text { error }\end{array}$ \\
\hline \multirow{3}{*}{ VCB1 } & yield\% & 79.91 & 79.97 & -0.075 \\
\hline & MS & $315.56 \%$ & 315.50 & 0.019 \\
\hline & DEE & $96.71 \%$ & $96.67 \%$ & 0.041 \\
\hline \multirow{3}{*}{ VCB2 } & yield\% & 82.15 & 82.11 & 0.048 \\
\hline & MS & $319.94 \%$ & 319.94 & -0.990 \\
\hline & DEE & $77.26 \%$ & $77.19 \%$ & 0.090 \\
\hline \multirow{3}{*}{ VCB3 } & yield\% & 81.45 & 81.47 & -0.024 \\
\hline & MS & $320.07 \%$ & 320.27 & -0.064 \\
\hline & DEE & $76.14 \%$ & $76.15 \%$ & -0.013 \\
\hline \multirow{3}{*}{ VCB4 } & yield\% & 80.69 & 80.67 & 0.024 \\
\hline & MS & $319.96 \%$ & 319.93 & 0.009 \\
\hline & DEE & $75.29 \%$ & $75.17 \%$ & 0.159 \\
\hline \multirow{3}{*}{ Optimized batch } & yield $\%$ & 89.98 & 89.95 & 0.033 \\
\hline & MS & $333.32 \%$ & 333.30 & 0.006 \\
\hline & DEE & $82.61 \%$ & $82.98 \%$ & -0.447 \\
\hline
\end{tabular}

MS: Microsphere size, DEE: Drug entrapment efficiency

\section{DISCUSSION}

FTIR spectra (Figure 1) of pure L-arginine and formulated microspheres of $L$-arginine shows the identical peaks as that of standard L-arginine which proves that excipients incorporated 


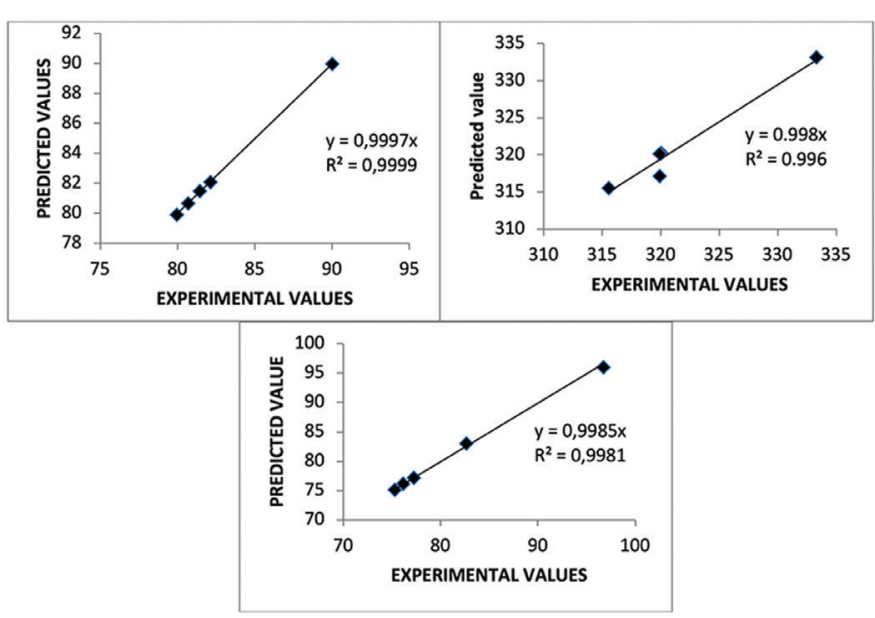

Figure 6. Regression coefficient between predicted and experimental response: a) \% yield, b) microsphere size, c) drug entrapment efficiency

in formulated microspheres do not interact with L-arginine and all ingredients of beads are compatible with each other.

Scanning electron microscopy of microspheres of L-arginine shows well-rounded spheres with rough surface because of sudden cross linking of gelatin with glutaraldehyde. The particle size of the formulations was found to be between 320-351.11 $\mu \mathrm{m}$. It was observed that the mean particle size of formulated microspheres were decreased with respect to the increased the amount of ethyl cellulose in the formulation (Figure 2).

Results for drug entrapment efficiency indicates that as the concentration of EC increases the DEE increase which is due practically insoluble nature of hydrophobic polymer i.e. EC. DEE was increased as the amount of EC was increased in the formulation because of practically insoluble nature of EC in water.

In vitro drug release study of microspheres of $\mathrm{L}$-arginine was carried out in $900 \mathrm{~mL}$ of phosphate buffer solution ( $\mathrm{pH}=7.4$ for $8 \mathrm{~h}$ ) at $37 \pm 0.5^{\circ} \mathrm{C}$. In the fasted state gel micro carriers exhibited a biphasic release profile as an initial rapid drug release phase due to burst which are loosely into or just beneath the surface of microspheres followed by a slower, gradually decreasing drug release phase after 1 hour extending up to 8 hours (Table 4, Figure 3).

Drug release mechanism was investigated for number of models i.e. zero-order, first order, Higuchi's square root of time model and Korsmeyer-Peppas model. Zero-order, first order, Higuchi's square root of time and Korsmeyer-Peppas model gave $\mathrm{R}^{2}$ value 0.9101 to $0.9473,0.9832-0.9889,0.9901$ 0.9992 and 0.963-0.991 respectively, showing Fickian diffusion involving a combination of swelling, diffusion and/or erosion of matrices. Various response surface plots were also drawn to analyse impact of independent variables on dependent variables as discussed earlier.

Optimizations of formulated microspheres were done by using $32 \mathrm{CCD}$. The outcomes for response parameters, that is, $\%$ yield, MS and DEE were subjected to regression analysis and statistical models were found to be significant. Observed dependent responses i.e. \% yield, MS and DEE shows fair relation between the dependent and independent variables. Percentage yield for formulated batches were found in the range of 74.65$86.36 \%$ while particle size was found in range of $302.34-333.32$ $\mathrm{mm}$. Drug entrapment efficiency of all the formulation was found to be between $73.59 \pm 1.744$ to $82.61 \pm 0.700$.

Figure 4a shows that values of \% yield, increases with increase in concentration of gelatin and also increases with increasing EC concentration. Maximum \% yield is observed at the highest levels of Gelatin and EC.

Figure 4b shows a nearly linear ascending pattern for MS, as the content of gelatin increased, this MS increase slowly with increasing gelatin. Value of MS achieves to its maximum value at the highest levels of gelatin and EC. Nonlinear pattern of contour lines indicates significant impact on gelatin and EC.

Figure $4 \mathrm{C}$ shows that the DEE increases almost linearly with increase in concentration of gelatin whereas it decreases very slowly and then increases with increase in EC concentration. Maximum value of DEE was observed at the highest gelatin and EC concentration.

Validation of optimized batch was done by setting up a comparison of the observed responses with the predicted ones (Table 5), the prediction error varied between -0.024 to $0.048,-0.990$ to 0.090 and -0.013 to 0.159 for \% yield, MS and DEE respectively. Validation of these data was also confirmed by overlay plot (Figure 5) obtained by design expert software (Dx8 trial version) The linear correlation plots drawn between the predicted and observed responses, forcing the line through the origin, demonstrated high values of $\mathrm{R}$ (0.996 to 0.999 , Figure 6), indicating excellent goodness of fit ( $p<0.005$ ). The corresponding residual plots show nearly uniform and random scatter around the mean values of response variables.

\section{CONCLUSIONS}

Spherical amino acid loaded gelatin microspheres were prepared to achieve repressible release by cross-linking technique. An L-arginine stacked repressible release matrix delivery system was successfully established and escalation was achieved by using $\mathrm{QbD}$ applying a $3^{2}$ central composite design. Hence it can be concluded that $\mathrm{QbD}$ is a powerful tool for the present research that helps in developing a desired formulation without wastage of time as well as manpower, money, and material.

Conflict of Interest: No conflict of interest was declared by the authors.

\section{REFERENCES}

1. Verma S, Lan Y, Gokhale R. Burgess DJ. Quality by Design approach to understand the process of nano susspension preparation. Int $\mathrm{J}$ Pharm. 2009;377:185-198.

2. Lionberger RA, Lee SL, Lee L, Raw A, Yu LX. Quality by Design: Concepts for ANDAs. AAPS J. 2008;10:268-276. 
3. Singh, B, Pahuja S, Kapil R, Ahuja N. Formulation development of oral controlled release tablets of hydralazine: optimization of drug release and bioadhesive characteristics. Acta Pharm. 2009;59:1-13.

4. Singh L, Nanda A, Sharma S, Sharma V. Performance Optimization of Buoyant Beads of Anti-Diabetic Drug Using Quality by Design (QbD). Lat Am J Pharm. 2014;33:14-23.

5. Desai S, Bolton S. A floating controlled-release drug delivery system: in vitro-in vivo evaluation. Pharm Res. 1993;110:1321-1325.

6. Panos I, ACOSTA N, Heras A. New Drug delivery systems based on Chitosan. Curr Drug Discov Techol. 2008;5:333-341.

7. Patil JS, Kamalapur MV, Marapur SC, Kadam DV. Ionotropic gelation and polyelectrolyte complexation: the novel techniques to design hydrogel particulate sustained, modulated drug delivery system: a review. Digest Journal of Nanomaterials and Biostructures. 2010;5:241-248.

8. Suganeswari M, Senthil Kumar V, Anto SM. Formulation and evaluation of metoclopramide hydrochloride microbeads by ionotropic gelation method. Int J Pharm Bio Arch. 2011;2(Suppl 3):921-925.

9. Morris CR, Poljakovic M, Lavrisha L, Machado L, Kuypers FA, Morris SM Jr. Decreased arginine bioavailability and increased serum arginase activity in asthma. Am J Respir Crit Care Med. 2004:170:148-153.

10. Appleton J. Arginine: Clinical potential of a semi-essential amino acid. Alt Med Rev. 2002;7:512-522.

11. Sharma V, Singh L, Verma N, Kalra G. The nutraceutical amino acidsnature's fortification for robust health. Br J Pharm Res. 2016;11:1-20.

12. Esposito E, Cortesi R, Nastruzzi C. Gelatin microspheres: influence of preparation parameters and thermal treatment on chemico-physical and biopharmaceutical properties. Biomaterials. 1996;17:2009-2020.
13. Vandelli MA, Rivasi F, Guerra P, Forni F, Arletti R. Gelatin microspheres crosslinked with D,L-glyceraldehyde as a potential drug delivery system: Preparation, characterization, in vitro and in vivo studies. Int J Pharm. 2001;215:175-184.

14. Mishra B, Sahoo S, Biswal PK, Sahu SK, Behera BC, Jana GK. Formulation and Evaluation of Torsemide intragastric buoyant sustained release microspheres. 2010;3:742-746.

15. Wagner JG. Interpretation of percent dissolved-time plots derived from in vitro testing of conventional tablets and capsules. J Pharm Sci.1969;58:1253-1257.

16. Sato $Y$, Kawaafaima $Y$, Takenchi $H$, Yamamoto $H$. In vitro and in vivo evaluation of riboflavin containing microoballoons for floating controlled delivery system in healthy humans. Int J Pharma. 2004;275:75-82.

17. USP, (24th ed) (Rockville: United States Pharmacopeial Convention Inc; 2000;1941-1943.

18. Obreshkova D, Ivanov K. Quality Control of Aminoacids in Organic Foods and Food Supplements. Int J Pharmacy Pharmaceutical Sciences. 2012;4:404-409.

19. Ritger PL. Peppas NA. A simple equation for description of solute release II. Fickian and anomalous release from swellable devices. J Controlled Release. 1987;5:37-42.

20. Korsmeyer RW, Gurny R. Doelker E, Buri P, Peppas NA. Mechanisms of solute release from porous hydrophilic polymers. Int J Pharmaceutics. 1983;15:25-35.

21. Higuchi T. Mechanism of sustained-action medication: Theoretical analysis of rate of release of solid drugs dispersed in solid matrices. $J$ Pharm Sci. 1963;52:1145-1149. 